\title{
Processing Solid Waste of Animal Beef using Bioactivators in Effort to Reduce Environmental Pollution
}

\author{
Titik Mariyati ${ }^{1}$, Indasah $^{2}$ \\ ${ }^{1}$ SMK Kesehatan Bhakti \\ Indonesia Medika Kediri \\ ${ }^{2}$ Institute of Healh Sciences \\ Strada Indonesia \\ Email: \\ titik.mariyati@ymail .com
}

Received : October $4^{\text {nd }} 2021$

Accepted : October $15^{\text {rd }} 2021$

Published : November $27^{\text {th }} 2021$

\begin{abstract}
Cattle waste both in the form of solid and liquid waste that is produced every day if left alone without proper waste treatment, it can cause environmental pollution, namely air, water, and soil pollution. The environment becomes squalid and attracts various animals such as flies and dogs which can carry various diseases such as deare, typhoid, cholera and skin diseases which can spread quickly and smell bad. One of the efforts to overcome environmental pollution around cattle is to carry out a composting process using cow rumen bioactivator. This study aims: (1) to find out whether cow rumen bioactivator can reduce the unpleasant odor caused by cattle waste, (2) find out whether cow rumen bioactivator can accelerate the composting process, (3) determine the effect of bioactivator volume on compost quality, namely nitrogen content. (N-total), Phosphorus levels, and Potassium levels. This study uses qualitative analysis to test odors ( $\mathrm{H} 2 \mathrm{~S}$ gas, $\mathrm{CO} 2$ gas, $\mathrm{NH} 3$ gas and $\mathrm{CH} 4$ gas) which was carried out at the CHEMICAL Laboratory of SMK Kesehatan Bhakti Indonesia Medika Kediri, and quantitative analysis to test Nitrogen levels using a Kjeldahl flask, Phosphorus levels with a visible spectrophotometer. , Potassium levels with AAS conducted at the Laboratory of PTPN X Jengkol Plosoklaten Kediri. This study showed: (1) after the composting process, cattle solid waste did not smell, (2) the composting process took 30 days, (3) the addition of various bioactivators $(25 \mathrm{ml}, 50 \mathrm{ml}, 75 \mathrm{ml}$, and $100 \mathrm{ml}$ ), volume $50 \mathrm{ml}$ is the optimal volume in the composting process with $3 \mathrm{~kg}$ of cattle solid waste. From the decomposition results, total nitrogen content was $0.592 \%$, phosphorus content was $0.27 \%$, and potassium content was $0.538 \%$. These levels meet the Quality Standards for organic fertilizers and soil enhancers according to the Regulation of the Minister of Agriculture no. 2/Pert./HK.060/2/2006.
\end{abstract}

Keywords: Environmental pollution, cattle solid waste, cow rumen bioactivator, variations of bioactivator

Copyright @ 2021 IIK STRADA Indonesia All right reserved.

International License. 


\section{INTRODUCTION}

Livestock waste can be in the form of solid (faeces), liquid (urine), and gas (H2S, NH3, CO2 and $\mathrm{CH} 4$ ). Untreated livestock waste will be a source of pollutants for water, air, and soil pollution.

As many as 55\% of the people in Jimbir Sugihwaras Prambon Nganjuk village are cattle and goats. The livestock waste produced consists of solid waste in the form of animal feces and feed residues, as well as liquid waste in the form of cage washing wastewater, livestock sanitation wastewater and livestock urine. If not handled properly, the livestock waste has the potential to cause environmental pollution and health problems for the community around the farm.

Cattle that have to produce solid, liquid and gas waste every day. The solid waste of cattle produced in rearing activities has been left untreated, left alone, it will make the solid waste of cattle accumulate more and more and there is no special place used to accommodate the waste, it will be a complicated problem for the environment. around the barn. This is what causes a dirty environment and becomes a breeding ground for harmful microorganisms such as worms or flies. In addition, the solid waste of cattle also causes an unpleasant / pungent odor around the cattle pens. Generally, livestock manure is thrown away or simply placed around the cage environment without any effective treatment, this will cause the cage environment to become dirty, and in months if it is not immediately handled to become compost, the livestock manure will cause environmental pollution in the form of air pollution from the unpleasant odor caused by the manure, and can also cause the environment to become slum, and attractive to various animals, such as flies and dogs, which can carry disease. Potential health hazards that can be caused such as diarrhea, cholera, typhoid and mold can spread quickly, because improperly managed waste can mix with drinking water and spread disease viruses. (Hidayat, 2017). Thus, to keep the environment around cattle farmers clean and healthy, it is necessary to process cattle solid waste into solid organic fertilizer in a relatively short time of 3 to 4 weeks with the addition of a bioactivator.

Bioactivator, also known as Effective Microorganism (EM) is a collection of various fermentative microbes, which function in the fermentation of organic materials. There are five main groups of fermentative microbes including: photosynthetic bacteria, Lactobacillus, Streptomyces, yeast (yeast), and Actinomycetes (Wiryanti, 2014). From this problem, it is hoped that the processing of cattle solid waste with the addition of a bioactivator is expected to reduce environmental pollution

Processing of cattle manure needs to be done to reduce environmental pollution, by treating cattle waste as manure because it contains nutrients such as nitrogen $(\mathrm{N})$, phosphorus $(\mathrm{P})$, and potassium (K) as well as micro nutrients including calcium, magnesium, sulfur. , sodium, iron, and copper needed by plants and soil fertility (Hapsari, 2013) Therefore, before being disposed of or used as fertilizer or soil enhancer, these materials must be stabilized first so as not to negatively affect the soil and plants.

\section{MATERIALS AND METHODS}

\section{Types of research}

The type of research used in this research is real research (True Experiment). Using True Experiment (real research) because the subject group (test substance) was chosen randomly, there was a comparison group to the group being treated, and there was control over the conditions in order to minimize the influence of other variables (interfering).

According to Sumadi Suryabrata (1990: 32-36) True Experiment aims to investigate the possibility of a causal relationship with the design where in fact there is a treatment group and a control group that is not subject to treatment conditions.

\section{Research design}

Research design is the methods used to collect research data so that research can be proven. In this study, the "pretest-posttest control groups design" was used, namely that there were two groups selected at random, then given a pretest to determine whether there was a difference between the experimental group and the control group in the initial state. Pretest results are good if the experimental group scores are not significantly different.

The research design used in this study was a "pretest-posttest control groups design", namely a research design that contained a pretest before being given treatment and a posttest after being given treatment. Thus it can be known more accurately, because it can be compared with being held before being given treatment. ( Sugiyono, 2001:64 ), 
Processing Solid Waste of Animal Beef using Bioactivators.....

Table of Research Design Pretest Posttest Control Group Design

\begin{tabular}{|c|c|c|c|}
\hline Kelompok & Pretest & Perlakuan & Posttest \\
\hline E & P1 & X & P2 \\
\hline K & P3 & - & P4 \\
\hline
\end{tabular}

Information :

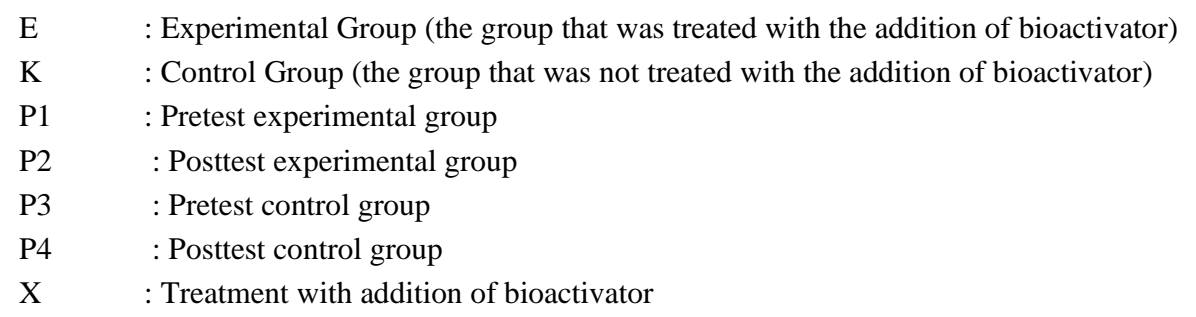

Image of the pretest-posttest control groups design:

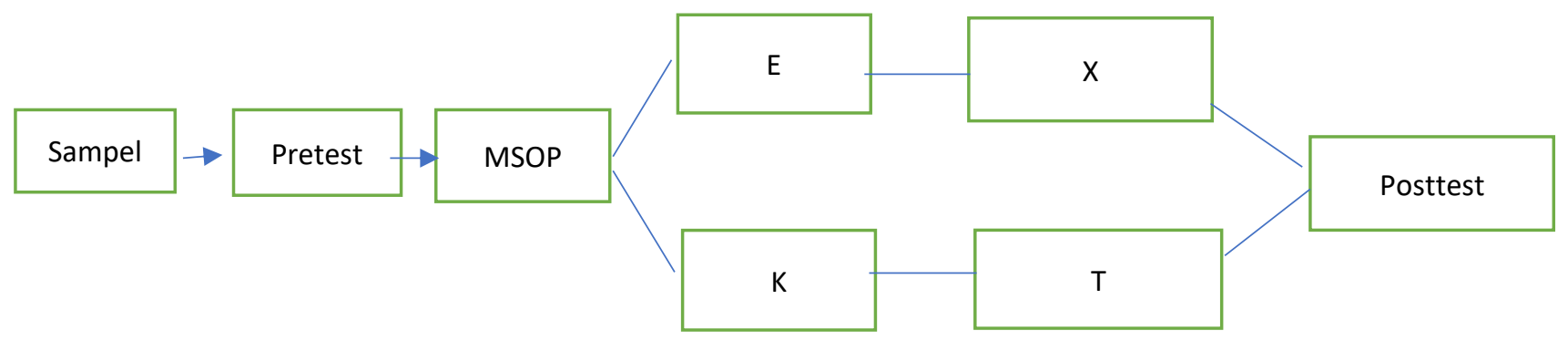

Information :

$\begin{array}{ll}\text { Sample } & : \text { Test Substance (bovine solid waste) } \\ \text { Pretest } & : \text { Initial test } \\ \text { MSOP } & : \text { Matched Subject Ordinal Pairing } \\ \mathrm{E} & : \text { Experimental Group } \\ \mathrm{K} & : \text { control group } \\ \mathrm{X} & : \text { Treatment with addition of bioactivator } \\ \mathrm{T} & : \text { Without the addition of bioactivator treatment } \\ \text { Posttest } & : \text { Final test }\end{array}$

The composting results from this experiment were compared with the Quality Standards for organic fertilizers and soil enhancers according to the Regulation of the Minister of Agriculture No. 2/Pert./HK.060/2/2006

Table 1. Minimum Technical Requirements for Organic Fertilizer

\begin{tabular}{|c|c|c|c|c|}
\hline \multirow[t]{2}{*}{ No } & \multirow[t]{2}{*}{ Requirements } & \multirow[t]{2}{*}{ Unit } & \multicolumn{2}{|c|}{ Parameters } \\
\hline & & & solid & liquid \\
\hline 1 & C-Organic & $\%$ & $>12$ & $\geq 4,5$ \\
\hline 2 & $\mathrm{C} / \mathrm{N}$ ratio & $\%$ & $10-25$ & \\
\hline 3 & Follow-up materials (gravel, glass, plastic, etc.) & $\%$ & Maks 2 & \\
\hline \multirow[t]{2}{*}{4} & Granule & $\%$ & $4-12$ & \\
\hline & bulk & & $13-20$ & \\
\hline \multirow[t]{5}{*}{5} & Heavy metal content & & & \\
\hline & As & $\mathrm{ppm}$ & $\leq 10$ & $\leq 10$ \\
\hline & $\mathrm{Hg}$ & $\mathrm{ppm}$ & $\leq 1$ & $\leq 1$ \\
\hline & $\mathrm{Pb}$ & $\mathrm{ppm}$ & $\leq 50$ & $\leq 50$ \\
\hline & $\mathrm{Cd}$ & $\mathrm{ppm}$ & $\leq 10$ & $\leq 10$ \\
\hline 6 & $\mathrm{PH}$ & & $4-8$ & $4-8$ \\
\hline \multirow[t]{3}{*}{7} & Total rate & & & \\
\hline & $\mathrm{P} 2 \mathrm{O} 5$ & $\%$ & $<5$ & $<5$ \\
\hline & $\mathrm{K} 2 \mathrm{O}$ & & $<5$ & $<5$ \\
\hline \multirow[t]{8}{*}{8} & Micro Elements & $\%$ & & \\
\hline & $\mathrm{Zn}$ & & Max 0.5 & Max 0,25 \\
\hline & $\mathrm{Cu}$ & & Max 0.5 & Max 0,25 \\
\hline & $\mathrm{Mn}$ & & Max 0.5 & Max 0,25 \\
\hline & Co & & Max 0,002 & Max 0,0005 \\
\hline & B & & Max 0,25 & $\operatorname{Max} 0,125$ \\
\hline & Mo & & Max 0,001 & Max 0,001 \\
\hline & $\mathrm{Fe}$ & & Max 0,4 & Max 0,004 \\
\hline
\end{tabular}

Sumber : Direktorat Sarana Produksi, 2006 
Processing Solid Waste of Animal Beef using Bioactivators.....

Table 2. Nutrient and Water Content of Several Types of Manure

\begin{tabular}{|c|c|c|c|c|c|}
\hline \multirow[t]{2}{*}{ Type of Livestock } & \multicolumn{4}{|c|}{ Nutrient and Water Content ( \% ) } & \multirow[t]{2}{*}{ Information } \\
\hline & Nitrogen & Information & Potassium & Water & \\
\hline \multicolumn{6}{|l|}{ Cow } \\
\hline Congested & 0,40 & 0,20 & 0,10 & 85 & Cold fertilizer \\
\hline Liquid & 1,00 & 0,50 & 1,50 & 92 & \\
\hline \multicolumn{6}{|l|}{ Buffalo } \\
\hline Congested & 0,60 & 0,30 & 0,34 & 85 & Cold fertilizer \\
\hline Liquid & 1,00 & 0,15 & 1,50 & 92 & \\
\hline \multicolumn{6}{|l|}{ Goat } \\
\hline Congested & 0,60 & 0,30 & 0,17 & 60 & Hot fertilizer \\
\hline Liquid & 1,50 & 0,13 & 1,80 & 85 & \\
\hline \multicolumn{6}{|l|}{ Sheep } \\
\hline Congested & 0,75 & 0,50 & 0,45 & 60 & Hot fertilizer \\
\hline Liquid & 1,35 & 0,05 & 2,10 & 85 & \\
\hline Chicke & 1,00 & 0,80 & 0,40 & 55 & Cold fertilizer \\
\hline
\end{tabular}

Sumber : Ade Iwan Setiawan, 2007

\section{Research Location and Time}

\section{Locations The research was conducted at:}

A. The fermentation process is carried out in a cowshed in Jimbir Hamlet, RT 02 RW 08 Sugihwaras, Prambon District, Nganjuk Regency.

B. Tests for Nitrogen, Phosphorus, and Potassium levels were carried out at the Sugar Research Center Laboratory of PTPN X in Plosoklaten Kediri.

C. Testing the qualitative analysis at the CHEMICAL Laboratory of SMK HEALTH BHAKTI INDONESIA MEDIKA KEDIRI

\section{Research time}

The research was carried out for 2 months, starting from May 1, 2021 to June 30, 2021.

\section{Tools and materials}

The tools and materials in the research consisted of 2 kinds, namely:

A. Tools and materials used in the cage as an experiment (composter)

1. Equipment in the fermentation process

Tong, gloves, measuring cup, mask, plastic bag, bucket, hoe, arco, water hose, scale ( balance ), thermometer, scissor, spray bottle, raffia, elastic rubber, book, pen.

2. Ingredients in the fermentation process

Fresh cow dung (rumen), molasses, coconut water, rice bran, rotting fruit residue, solid cow dung, well water.

B. Tools and materials for the analysis of compost quality parameters. at the Research Center Laboratory of PTPN X Plosoklaten Kediri.

1. Tools for analyzing compost quality parameters

Analytical balance with $0.1 \mathrm{mg}$ accuracy, degeston apparatus (electric heater), distillation unit, Kjeldahl flask, burette, dispenser, Erlenmeyer flask, volume pipette, $50 \mathrm{ml}$ or $100 \mathrm{ml}$ volumetric flask, Digestion flask, microwave digester, 20 volume chemical tube ml, Vortex mixer, Visible Spectrophotometer, AAS (Atomic Absorbance Spectrophotometer), Cathode lamp K.

2. Materials on compost quality parameter analysis

Water, concentrated $\mathrm{H} 2 \mathrm{SO} 4$, sulfuric-salicylic acid solution (dissolved $25 \mathrm{~g}$ of salicylic acid in 1 liter of concentrated sulfuric acid, sodium thiosulfate, standard solution of $\mathrm{H} 2 \mathrm{SO} 40.05 \mathrm{~N}$, Boric acid $1 \% \mathrm{w} / \mathrm{v}$, Conway indicator (added $0.15 \mathrm{~g}$ bromo cresol green $+0.1 \mathrm{~g}$ methyl red in $100 \mathrm{ml}$ alcohol $96 \%$ ), NaOH $40 \%, \mathrm{HNO} 3$ $65 \%, \mathrm{HClO} 470 \%, \mathrm{KH} 2 \mathrm{PO} 4$, Phosphate Molybdate reagent, $\mathrm{LaCl} 3$

\section{Research Implementation Design}

This study used a randomized design consisting of 20 formulations of compost material to be treated, as follows:

$\mathrm{P} 0=3 \mathrm{~kg}$ of solid cow dung (normal) 
$\mathrm{P} 1=3 \mathrm{~kg}$ cow dung $+25 \mathrm{ml}$ cow rumen bioactivator

$\mathrm{P} 2=3 \mathrm{~kg}$ cow dung $+50 \mathrm{ml}$ cow rumen bioactivator

$\mathrm{P} 3=3 \mathrm{~kg}$ cow dung $+75 \mathrm{ml}$ cow rumen bioactivator

$\mathrm{P} 4=3 \mathrm{~kg}$ cow dung $+100 \mathrm{ml}$ cow rumen bioactivator

\section{Research Stages}

Each treatment was repeated 5 times, so that 20 experimental plastic bags were obtained

The research was conducted through 3 stages, namely:

1. Introduction Stage

The introductory stage is the stage that begins with the collection of cow rumen and cow solid manure

2. Experimental stage

The experimental stage is divided into 2, namely:

2.1. Stages of making bioactivator

a. $10 \mathrm{~kg}$ of beef rumen plus 1 liter of molasses later

b. plus $5 \mathrm{~kg}$ of rice bran which is then diluted with enough coconut water, then

c. placed in a barrel, allowed to ferment for 1 week.

d. After fermentation occurs, it is filtered, then the filtrate is added to the rest of the rotten fruit.

e. The bioactivator is ready to use.

2.2. The implementation stage of the research was to put $3 \mathrm{~kg}$ of solid cow dung into a plastic bag then add a variety of bioactivators from the cow's rumen and put it in a plastic bag and then put the bucket in a closed room.

3. Decomposition analysis stage

The decomposition analysis stage is that during the decomposition process until the composting process is complete, several measurements are carried out once a week including measurements of temperature, $\mathrm{pH}$, color and odor. After the compost is formed, it is continued by analyzing the levels of Nitrogen, Phosphorus, and Potassium, and qualitative analysis of odor.

\section{Sampling Technique}

Sampling (test substance) using purposive sampling technique, which means the test substance is taken from cow dung that one day comes out of the stomach of cattle.

\section{Research variable}

1. Independent variable

The independent variables in this study include: Bioactivator volume

2. Bound Variable

The dependent variables in this study include: the weight of the test substance

\section{Data analysis}

(bovine solid waste), and the quality of the compost

1. Data Analysis Requirements

a. Data Distribution Normality Test

Normality test aims to determine whether a research data is normally distributed or not. In parametric statistical analysis, data with normal distribution is a must as well as an absolute requirement that must be fulfilled. If the data is not normally distributed, then the research hypothesis is tested using a non-parametric statistical analysis approach.

One way to detect the normality of a data can be done with the Kruskal-Wallis technique. The Kruskal-Wallis test is called the $\mathrm{H}$ test, which is an alternative procedure to the one-way ANOVA. Kruskal-Wallis is a non-parametric alternative method that can be used for ordinal response data or ranked data.

b. Data Homogeneity Test

The homogeneity test aims to determine whether the variation of some data from the population has the same variance or not. This homogeneity test serves as a 
requirement (though not an absolute requirement) in comparative analysis such as the independent sample $t$ test and ANOVA test.

According to Joko Widiyanto (2010:51) the basis or guidelines for decision making in the homogeneity test are as follows:

1. If the significance value or Sig. $<0.05$, it is said that the variance of two or more data population groups is not the same (not homogeneous).

2. If the significance value or Sig. > 0.05, it is said that the variance of two or more data population groups is the same (homogeneous).

2. Hypothesis Test

The data analysis technique used in this research is ANOVA analysis. This technique aims to determine the difference between the actualization of the composting process in the application of a bioactivator and the composting process without the addition of a bioactivator. The hypotheses that the researcher proposes are:

a. $\mathrm{H} 1$ or the first hypothesis: There is an effect of adding bioactivator to the time used in the composting process of cattle solid waste.

b. $\mathrm{H} 2$ or second hypothesis: There is an effect of adding a bioactivator to the smell of cattle solid waste.

c. H3 or third hypothesis: There is an effect of adding bioactivator to compost quality (content of N, P, K elements in cattle solid waste).

To test the research hypothesis above, we need to make a decision in the ANOVA test, the decision that can be obtained is by looking at the significance value (sig), based on the significance value ( $\mathrm{Sig}$ )

1. If the significance value $(\mathrm{Sig})<$ probability 0.05 , then there is an effect of the independent variable on the dependent variable, or the hypothesis is accepted.

2. If the significance value ( $\mathrm{Sig})>0.05$ probability, then there is no effect of the independent variable on the dependent variable, or the hypothesis is rejected.

\section{RESULTS}

In this section, the researcher will convey the results of the research which include:

A. Qualitative analysis stage

B. Decomposition analysis stage

A. Qualitative Analysis Stage

Examination Results Qualitative analysis.

\begin{tabular}{|c|c|c|c|c|c|c|c|c|}
\hline No & Zat Uji & H2S & CO2 & NH3 & CH4 & PH & Smell & color \\
\hline 1 & PB & + & + & + & + & 6,8 & $\begin{array}{c}\text { Not delicious and } \\
\text { pungent }\end{array}$ & yellowish \\
\hline 2 & PL & + & + & + & - & 6,8 & Not delicious & chocolate \\
\hline 3 & P1 & - & - & - & - & 6,8 & - & Dark chocolate \\
\hline 4 & P2 & - & - & - & - & 6,8 & - & Dark chocolate \\
\hline 5 & P3 & - & - & - & - & 6,8 & - & Dark chocolate \\
\hline 6 & P4 & - & - & - & - & 6,8 & - & Dark chocolate \\
\hline
\end{tabular}

B. Decomposition Analysis Stage

Compost Quality Measurement Results (N, P, K)

\begin{tabular}{|c|c|c|c|c|c|c|c|}
\hline \multirow{3}{*}{ Replication } & Treatment & \multicolumn{7}{|c|}{ Bioactivator Volume (\%) } \\
\cline { 2 - 8 } & Content & PB & PL & P1 & P2 & P3 & P4 \\
\hline \multirow{3}{*}{1} & $\mathrm{~N}$ & 0.31 & 0.58 & 0.58 & 0.58 & 0.55 & 0.59 \\
\cline { 2 - 8 } & $\mathrm{P}$ & 0.18 & 0.33 & 0.10 & 0.60 & 0.14 & 0.33 \\
\hline \multirow{3}{*}{$\mathrm{II}$} & $\mathrm{K}$ & 0.31 & 0.44 & 0.57 & 0.58 & 0.33 & 0.44 \\
\cline { 2 - 8 } & $\mathrm{N}$ & 0.31 & 0.58 & 0.56 & 0.6 & 0.61 & 0.45 \\
\hline
\end{tabular}


Processing Solid Waste of Animal Beef using Bioactivators.....

\begin{tabular}{|c|c|c|c|c|c|c|c|}
\hline & $\mathrm{K}$ & 0.31 & 0.44 & 0.52 & 0.52 & 0.37 & 0.38 \\
\hline \multirow{3}{*}{$\mathrm{III}$} & $\mathrm{N}$ & 0.31 & 0.58 & 0.58 & 0.60 & 0.60 & 0.59 \\
\cline { 2 - 8 } & $\mathrm{P}$ & 0.18 & 0.33 & 0.25 & 0.20 & 0.22 & 0.30 \\
\hline \multirow{3}{*}{$\mathrm{IV}$} & $\mathrm{K}$ & 0.31 & 0.44 & 0.55 & 0.56 & 0.56 & 0.58 \\
\cline { 2 - 9 } & $\mathrm{N}$ & 0.31 & 0.58 & 0.58 & 0.58 & 0.59 & 0.59 \\
\cline { 2 - 9 } & $\mathrm{P}$ & 0.18 & 0.33 & 0.20 & 0.15 & 0.21 & 0.22 \\
\hline \multirow{3}{*}{$\mathrm{K}$} & $\mathrm{N}$ & 0.31 & 0.58 & 0.32 & 0.60 & 0.61 & 0.60 \\
\cline { 2 - 9 } & $\mathrm{P}$ & 0.18 & 0.33 & 0.32 & 0.25 & 0.30 & 0.30 \\
\cline { 2 - 8 } & $\mathrm{K}$ & 0.31 & 0.44 & 0.54 & 0.57 & 0.58 & 0.58 \\
\hline
\end{tabular}

Information :

PB: Test substance that just came out of cattle

PL : Test substance without treatment left for 4 weeks

$\mathrm{P} 1$ : The test substance is treated with the addition of $25 \mathrm{ml}$ of bioactivator

$\mathrm{P} 2$ : The test substance is treated with the addition of $50 \mathrm{ml}$ of bioactivator

P3 : Test substance with the addition of $75 \mathrm{ml}$ of bioactivator

$\mathrm{P} 4$ : The test substance is treated with the addition of $100 \mathrm{ml}$ of bioactivator

\section{DISCUSSION}

In the compost maturation process, the degree of acidity ranges from PH 6 to 7 (neutral PH). The $\mathrm{pH}$ of the compost serves as an indicator of the compost decomposition process. Compost microorganisms will work to carry out their activities and grow at a PH between 5.5 to 8. ( PINLITAMAS 1: 2018

In the composting process, temperature is a very important factor in determining the proliferation of microorganisms. Microorganisms are bacteria that will decompose solid waste cow manure to become compost. At the beginning of composting the temperature of the test substance was $27 \mathrm{oC}$.

After an interval of 1 week (day 8 ) the temperature began to rise, the test substance without treatment (control) rose to $28^{\circ} \mathrm{C}$, while those with treatment increased significantly by $33{ }^{\circ} \mathrm{C}$ and 35 ${ }^{\circ} \mathrm{C}$. In this phase, microorganisms are present and begin to work on decomposing cattle solid waste.

In the second week (16th day) for the test substance without treatment (control) the temperature remained at $28{ }^{\circ} \mathrm{C}$, while the test substance with temperature treatment increased dramatically, here is the peak temperature of composting, i.e. some are at a temperature of $35^{\circ} \mathrm{C}$, some are a temperature of $36^{\circ} \mathrm{C}$ and there is a temperature of $37^{\circ} \mathrm{C}$.

In the third week (day 21) for the test substance without treatment (control) the temperature remained at $28{ }^{\circ} \mathrm{C}$, while for the test substance that was being treated the temperature began to drop, namely at a temperature of $30^{\circ} \mathrm{C}, 32{ }^{\circ} \mathrm{C}$ and $32{ }^{\circ} \mathrm{C}$. In this phase the activity of microbes (microorganisms) begins to decrease. This phase is known as the compost maturation phase.

On the fourth week (day 30) all the test substances were at $28{ }^{\circ} \mathrm{C}$ which is at room temperature. ( Article : Chem.Notes 2020 )

The temperature in the composting process gradually decreases due to reduced organic matter that can be decomposed by microorganisms. This can occur because the life of mesophilic and thermophilic microorganisms alternately. When the temperature drops, mesophilic microorganisms grow to replace thermophilic microorganisms. ( Journal.unnes.ac.id/sju/index.php/Unnes.JLifeSci, $2016)$ 
In the anaerobic composting process when added microorganisms (Bioactivator) it will last 30 days. .( Artikel : Perencanaan, Perancangan Lingkungan 2021)

\section{Nitrogen Content}

Figure From the decomposition process, the data obtained on the average levels of N, P, K are as :

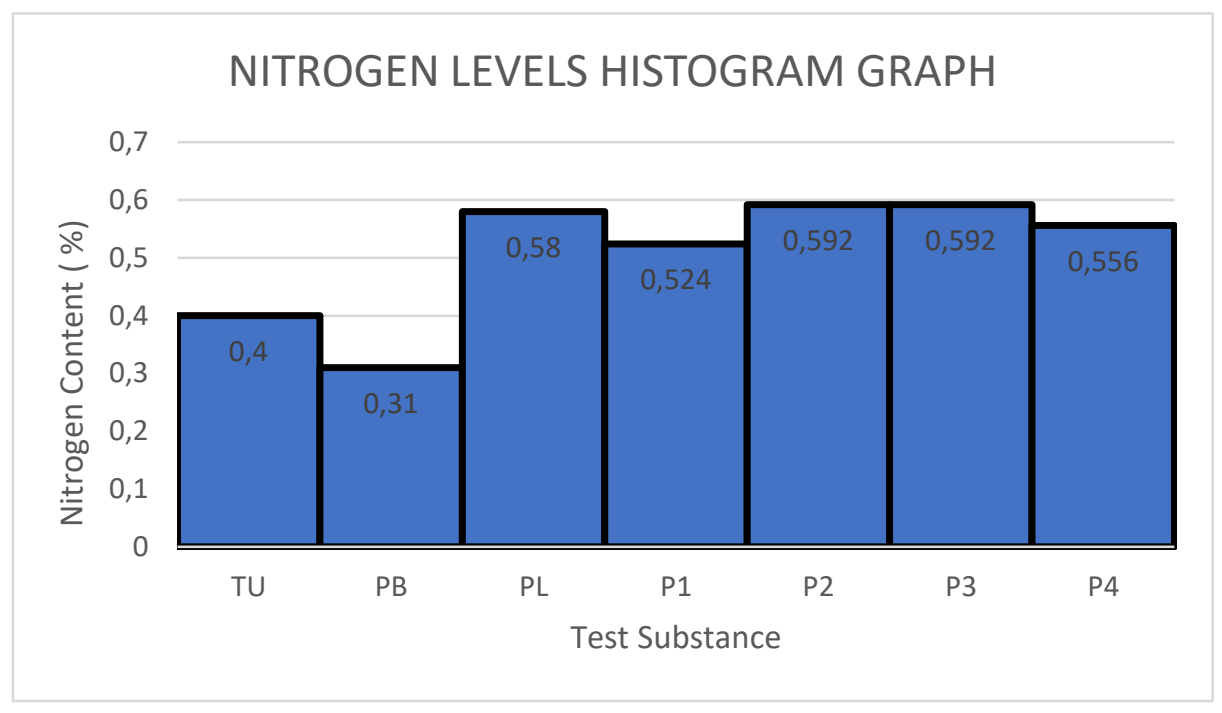

In the Nitrogen content histogram above, the standard Nitrogen content is $0.4 \%$. Nitrogen content in cattle solid waste that just came out of cattle $0.31 \%$ does not meet the standard of use.

Meanwhile, cattle solid waste that was left for 30 days without treatment had a concentration of $0.58 \%$ and that which was treated with added bioactivator met the appropriate standard for use because the level was already above 0.4\%. ( Setiawan, Ade Iwan. 2007)

Cattle solid waste that is left for 30 days and added with a bioactivator, the nitrogen content increases, this is because there is already a role for microorganisms that decompose cow solid waste.

Nitrogen levels from cattle solid waste that are left for 30 days without treatment are higher than nitrogen levels from livestock solid waste added with bioactivators, because in the decomposition process microorganisms also need nitrogen elements to maintain and form body cells. In addition, nitrogen can react with water to form NO3- and $\mathrm{H}+$. Where NO3- can occur decomposition reactions into N2 gas and N2O gas. ( Journal of Veterinary Science (1), June 2017) 


\section{Phosphorus Level}

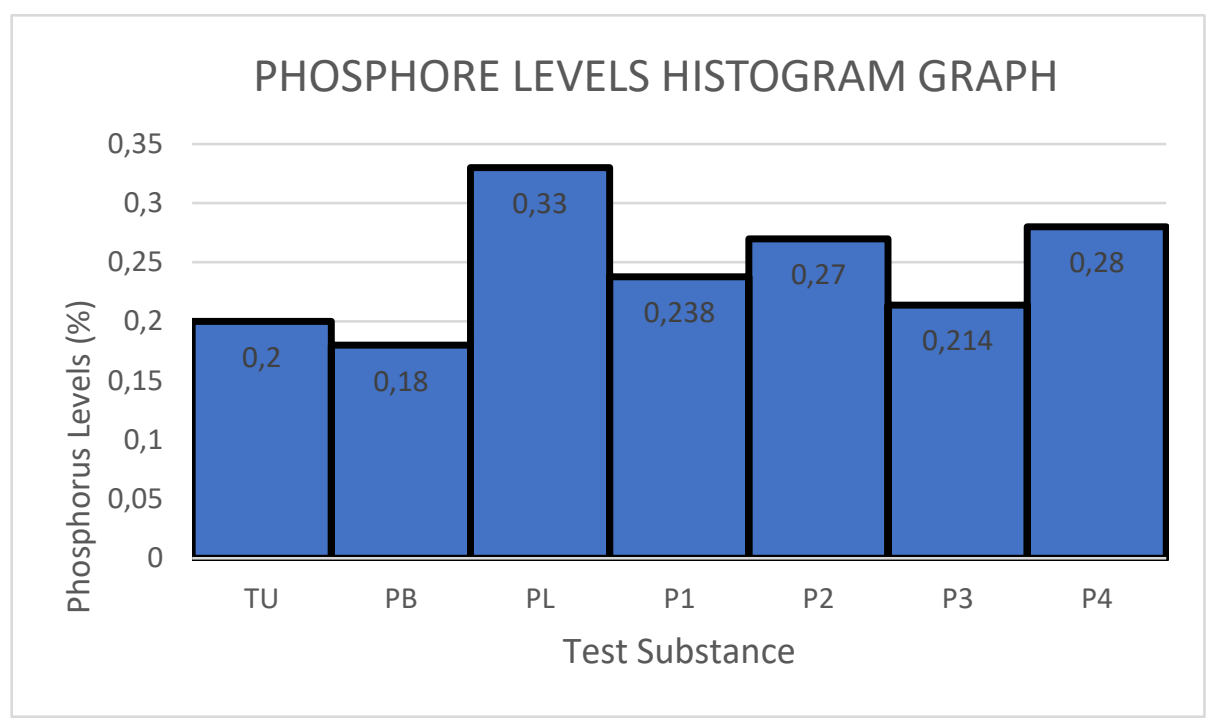

In the Phosphorus histogram above, the standard Phosphorus level is $0.2 \%$ suitable for use. Phosphorus levels in cattle solid waste that just came out of cattle $0.18 \%$ do not meet the standard. Meanwhile, cattle waste that was left for 30 days without treatment had a concentration of $0.33 \%$ and that which was treated with added bioactivator met the proper use standard because the level was already above 0.2\%. ( Setiawan, Ade Iwan. 2007 ), ( No.2/Pert./HK.060/2/2006 )

By leaving it for 30 days and adding a bioactivator, the Phosphorus content increases, this is because there is already a role for microorganisms that decompose solid cattle waste.

Phosphorus levels from cattle solid waste that were left for 30 days without treatment were higher than the levels of Phosphorus from livestock solid waste added with bioactivators, because in the process of decomposing cattle solid waste microorganisms in their activities also require Phosphorus elements. ( ISSN : 2621 - 1475, J.Fish Protech 2020, vol.3 No.2)

\section{Potassium Level}

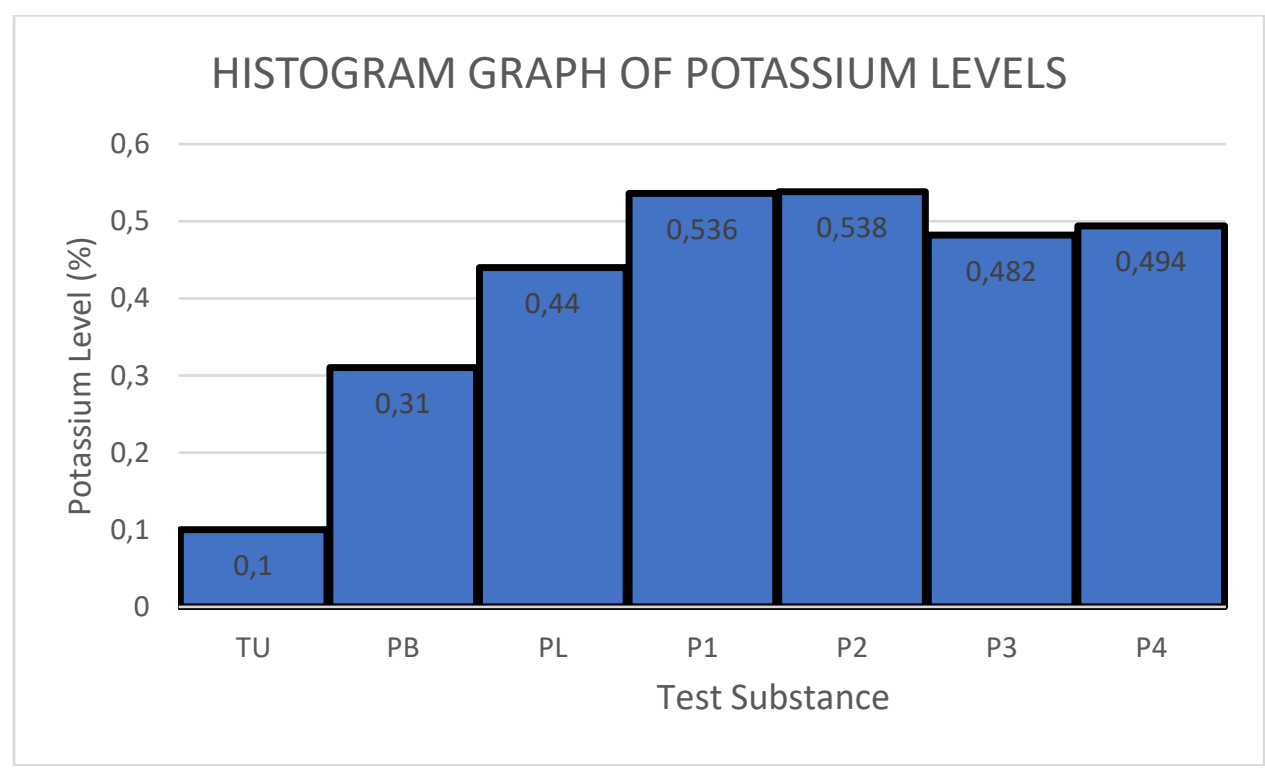


In the histogram of Potassium levels above, the standard Potassium level is $0.1 \%$ suitable for use. Potassium levels in cattle solid waste that just came out of cattle $0.31 \%$ meet the standard of use. ( Setiawan, Ade Iwan. 2007 ), ( No.2/Pert./HK.060/2/2006 )

Meanwhile, cattle solid waste that was left for 30 days without treatment had a concentration of $0.44 \%$ and that which was treated with added bioactivator met the proper use standards because the levels were already above $0.1 \%$.

Cattle solid waste that is left for 30 days and added with a bioactivator, the content of Potassium increases, this is because there is a role for microorganisms that decompose solid cattle waste.

Potassium levels from cattle solid waste that were left for 30 days without treatment were lower than Potassium levels from livestock solid waste added with bioactivator. Thus, the addition of a bioactivator greatly affects the composting process. Elemental Potassium is used by microorganisms in the substrate material as a catalyst, so that an increase in the activity of microorganisms will increase the level of Potassium. ( Journal of Veterinary Science (1), June 2017)

\section{CONCLUSION}

Based on the results of research and discussion, the following conclusions can be drawn:

1. The addition of a bioactivator can accelerate the composting process of cattle solid waste for 4 weeks (30 days), so as to create a clean and healthy environment.

2. The addition of a bioactivator can reduce unpleasant and pungent odors in cattle solid waste because $\mathrm{NH} 3, \mathrm{H} 2 \mathrm{~S}, \mathrm{CO} 2$ and $\mathrm{CH} 4$ gases have been decomposed into other elements $(\mathrm{N}, \mathrm{C})$ within 30 days, so as to reduce air pollution.

3. The optimal addition of a boactivator in the processing of cattle solid waste based on the quality of the compost is the addition of a $50 \mathrm{ml}$ bioactivator.

4. The quality of the compost (concentration of $\mathrm{N}, \mathrm{P}, \mathrm{K}$ ) has met the standards of the Regulation of the Minister of Agriculture No.2/Pert./HK. 060/2/2006.

5. Based on statistical tests, then:

a. The addition of bioactivator affects the formation of nitrogen nutrients.

b. The addition of bioactivator has no effect on the formation of Phosphorus nutrients

c. The addition of bioactivators affects the formation of potassium nutrients.

\section{Suggestion}

Based on the results of the study, suggestions can be given:

1. Further research is needed on E-Colli bacteria around cattle farmers.

2. Further research is needed on the content of other micro and macro nutrients from the beginning until compost is formed.

3. Further research is needed on the biological test of the composting process of cattle solid waste.

Website : http://jurnal.strada.ac.id/jqph Email : jqph@strada.ac.id

\section{REFERENCES}

Abbasi,S,A, (2013) Methane Capture From Livestock Manure. Journal Of Environmental Management 117. Hal 187

Arikunto, Suharsini. (2010). Prosedurb Pnelitian Suatu Pendekatan Praktik. Jakarta: Rineka Cipta, hal. 211.

Ardinal dkk ( 2015 ). Studi Potensi Pembentukan Biogas Dari Sampah Makanan Dan Ko-Substrat Fses Sapi Untuk Energi Listrik Alternatif, Journal Litbang Industri Vol. 5 No. 2 :101-111

Azhar, Iman ( 2012 ). Multivariate of Variance, ( Jurnal Studi Islam Madinah Vol. 7 No.1: hal 23

Azwar, S. (2015). Dasar-Dasar Psikometrika ( Edisi I I ). Yogjakarta: Pustaka Pelaajar.

Basri, Elma ( 2017 ). Potensi dan Pemanfaatan Rumen Sapi Sebagai Bioaktivator, Bogor, Kementerian Pertanian RI.

Budiman. Suyono. Fazriaty, Nadya ( 2018 ). Pengaruh Tiga Jenis Bioaktivator Ragi Terhadap Karakteristik Fisik Kompos Sampah Organik Di Rumah Sakit Cahya Kawaluyaan, vol. 1, No.1 ISSN 2654-5411

Ghozali, Imam. (2016). Aplikasi Analisis Multivariate Dengan Program IBM SPSS 23 ( edisi 8 ). Semarang : Bada Penerbit-UNDIP. 
Hidayat, Taufik. (2017, Marc 21). Sampah Membuat Jadi Kumuh dan Tidak Sehat. Propinsi Sumatera Utara. Retrieved from kotaku.pu.go.id

Irianto, Agus. (2007). Statistik Konsep Dasar \& Aplikasinya. Jakarta: Perada Media Group : hal. 271271

Niaga, Muhammad Syawal Akbar dkk ( 2020 ). Pengaruh Penambahan EM4 Yang Berbeda Terhadap Komposisi Hara Pupuk Organik Cair Berbahan Baku Limbah Kepala Udang Jenis Litopenaeus vannamei, volume 3 No. 2, ISSN : 2621-1475

Novitasari, Devi. Caroline,Jenny. (2021). Kajian Efektivitas Pupuk Dari Berbagai Kotoran Sapi, Kambing Dan Ayam. Makalah dipresentasikan di FTSP ITATS, Surabaya.

Nur, Thoyib dkk ( 2016 ). Pembuatan Pupuk Organik Cair dari Sampah Organik Rumah Tangga dengan Bioaktivator EM4, volume 5 No.2.e-ISSN: 2541-3481

Nurjanah, N .dkk ( 2019 ). Pembuatan Pupuk organic Padat Dengan Aerob, Journal of Chemical Process Engineering vol.4 No. 2 e-ISSN 2655-2967

Nurjasmi,Reni. Karakteristik Kompos Asal Berbagai Jenis Limbah Organik Dengan Penambahan Beberapa macam Bioaktivator. Jurnal Ilmiah Respati Pertanian ISSN : 141-7126, Vol.2. No. Hal 619-622

Nurkholis. (2019). Pembuatan Pupuk Organik Padat (POP) BerbasisBahan KOtoran Ternak Dengan Memanfaatkan Bioaktivator Isi Rumen Sapi. ISBN : 978-602-14917-8-2.Hal 170-172

Novitasari, Devi. Caroline,Jenny. (2021). Kajian Efektivitas Pupuk Dari Berbagai Kotoran Sapi, Kambing dan Ayam. Makalah dipresentasikan di FTSP ITATS, Surabaya.

Notoatmojo, Soekidjo. (2002). Metododologi Penelitian Kesehatan. Jakarta : Rineka Cipta, hal 46.

Peraturan Menteri Pertanian Nomor : 02/Pert/HK.060/2/2006

Ratrinia, Putri Wening.Uju, Pipih Suptijah ( 2016 ). Efektivitas Penambahan Bioaktivator Laut dan Limbah Cair Surimi Pada Karakteristik Pupuk Organik Cair Dari Sargassum sp, DOI: 10.17844/jphpi.2016.19.3.309

SNI ( 2018 ), Pupuk Organik Padat, Jakarta : SNI 7763:2018

Salawati, Trixie dkk ( 2008 ). Jurnal Promosi Kesehatan vol.3 No. 2

Setiawan,Ade Iwan. (2007). Memanfaatkan Kotoran Ternak ( edisi revisi ). Jakarta : Penebar Swadaya, hal. 12-18

Setiawan, Budi Susilo ( 2016 ). Bioaktivator, Beranda Dunia Tanaman

Sharot, Siddarth. ( 2019 ). Biodiesel Production Form Mutton Waste Fat -Ashort Review. Journal Of Enveronmental Science and Pollotion Resert http://doi.org/10.30799/jespr.168.19050204.page 346

Siregar, Syofian. (2014). Statistik Parametrik Untuk Penelitian Kuantitatif. Jakarta : Bumi Aksara : hal. $77-90$.

Sudantha, I.M. dan Sardian( 2016 ). Potensi Bioaktivator dan Biokompos ( Mengandung Jamur Tichrodermaspp. dan Mikoriza ) dalam Meningkatkan Kesehatan, Pertumbuhan dan Hasil Tanaman Kedelai di Lahan Kering. Eprints.unram.ac.id. hal $10-13$

Sugiyono. (2012). Metode Penelitian Pendidikan Pendekatan Kuantitatif, Kualitatif dan R \& D., Bandung : Alfabeta, hal.79

Tanzah, Ahmad. (2011). Metode Penelitian Praktis. Yogjakarta: Teras, hal. 9

Trivana,Linda. (2017). Optimalisasi Waktu Pengomposan dan Kualitas Pupuk Kandang dari Kotoran Kambing dan Debu Sabut Kelapa Dengan Bioaktivator PROMI dan Orgadec. JurnalSainVeterinerISSN : 2407 - 3733. Hal 140 - 142

Vogel. (1985). Buku Teks Analisis Anorganik Kualitatif Makro dan Semi Mikro Bagian II (edisi lima). Jakarta : PT. Kalman Media Pusaka, hal 317, 327.

Vogel. (1985). Buku Teks Analisis Anorganik Kualitatif Makro dan Semi Mikro Bagian I (edisi lima). Jakarta : PT. Kalman Media Pusaka, hal 311

Wellang, Rahma Musafir. Rahim, Irwan Ridwan. (2015). Study Kelayakan Kompos Menggunakan Variasi Bioaktivator. Makalah dipresentasikan di Fakultas Teknik UniversitasHasanudi, Makasar

W.Deasy Amalia, Widiyaningrum, Priyantini ( 2016 ). Penggunaan EM4 dan MOl Limbah Tomat Sebagai Bioaktivator Pada Pembuatan Journal.unnes.ac.id/sju/index.php/Unnes.JLifeSci, p-ISSN2252-6277 